\title{
INSECTICIDAL ACTIVITY OF SELECTED CHEMICALS AND BIOPESTICIDES AGAINST COWPEA AND KHAPRA BEETLES, AND THEIR SUB-LETHAL TOXICITY ON THE JAPANESE QUAIL
}

\author{
H.M. Elzun(1), Sh.E. El-Hamady(2), A.A. Gazzy(3) and A. A. Salem(1) \\ (1) Dept. of Stored Product Pests, Plant Protection Res. Inst., Agric. Res. Center, Giza \\ (2) Dept. of Pesticides, Faculty of Agriculture, Kafr Elshiekh University \\ (3) Dept. of Zology, Faculty of Science , Kafr Elshiekh University
}

Received: May 2, 2019

Accepted: Jun. 25, 2019

\begin{abstract}
The widespread use of synthetic insecticides have been caused a serious hazards to human and the environment. So, the present study aimed to evaluate newer approaches that achieve efficient insecticidal activity for controlling cowpea and khapra beetles, meanwhile leading to no detrimental effects. In this respect, the following tools were investigated: Acutely toxic chemicals, mostly of natural origin, i.e. Vertemic, Ivomic, Agrothrin and Neemix. Some toxicological and environmental aspects of some tested chemicals were also evaluated. The results showed considerable and remarkable insecticidal activity, in particular, ivomic against the tested insects (i.e. cowpea beetle, Callosobruchus maculatus $F$., and khapra beetle, Trogoderma granarium E.) under storage conditions (Viz. lacking of direct light and other weathering factors). Pyrethrins might be photostable, hence they revealed long residual toxicity when applied on grains. Moreover, the results showed that ivomic and agrothrin were highly effective. Also, neemix showed considerable feeding deterrent effects against larvae of khapra beetle, $T$. granarium at concentrations $\geq 125 \mathrm{mg} / \mathrm{kg}$ grains. Howerver, neemix or ivomic showed harmful effects on the liver function of Japanese quail birds treated with repeated daily doses each of $1 / 100$ or $1 / 500 L D_{50}$ for 21 consecutive days, where levels of alanine amino transferase, alkaline phosphatase and total bilirubin were significantly altered in the serum of treated birds. Furthermore, the number of egg laid by treated birds showed significant reduction by $75 \%, 65 \%$, and $60 \%, 35 \%$, for neemix and ivomic at $1 / 100$ and $1 / 500$ $L D_{50}$, respectively. These effects were ascertained by the histopathological examinations. Also the present study used Actellic and Malathion as standard referance agents against stored product insects.
\end{abstract}

Key words: Stored product insects, Ivormic, Agrothrins, Neemixs, Japanese quail, liver function, histopathological examinations.

\section{INTRODUCTION}

Stored grain of almost any kind is subject to attack by insects, which are highly specialized and in most cases are of small size with a high reproductive potential. Therefore, they are easily concealed in grain and have been carried to all parts of the world. Once established in a commodity they are usually difficult to control (Koehler, 2003). C. maculatus causes substatial losses to the pulses in the storage throughout the world (RighiAssia et al. 2010). It is know to cause up to $100 \%$ loss of stored cowpea (Jaki and Daoust, 1986). The khapra beetle, Trogoderma granarium (Everts) is one of the most serious insect pest in tropical and suptropical region of Assia and Africa (Atwal,1976; Salunkhe et al. 1985 and Viljoen, 1990) The increased use of insecticides as means of crop protection led to many health problems in human and ambient environment. (Benbrook, 1991). The potential hazards for mammals from the conventional insecticides, the ecological 
consequences and the increase of insect resistance to these insecticides have led to a search of newer advantadgeous classes of insecticides. Avermectins, a family of macrocyclic lactones are natural product pesticides isolated from the fermentation of the soil microorganism., Streptomyces avermitilis and they have potent anthelmintic, acaricidal as well as insecticidal properties (Miller et al., 1979; Fisher and Morzik, 1989; Burg and Stapley 1989; Wehner, et al., 1993 and Shoop et al., 1995). Also agrothrin as one of the natural pyrethrins gave effective grain protection against Sitophlus zeamais, it caused mortalities more than $95 \%$ of insects after 5 and 6 weeks (Hategekimana, 2017). The most prominent constituent of neem is azadirachtin, which has been established as a pivotal insecticidal ingredient. It acts as an antifeedant, repellent, and repugnant agent and induces sterility in insects by preventing oviposition and interrupting sperm production in males. (Chaudhary, et. al, 2017). A significant reduction of food consumed by the $4^{\text {th }}$ and $6^{\text {th }}$ instar larvae of of the Spodoptera littoralis were treated with sublethal concentrations of Nimbecidine $\mathbf{( 0 . 0 3 \%}$ Azadirachtin) was reprted by (Ghoneim and Hamadah, 2017). Azadirachtin is a tetranortriterpenoid compound belonging to the limonoids, which can be isolated from the Neem tree, Azadirachta indica A. Juss. The potential of azadirachtin and azadirachtin-containing extracts has been explored for use in integrated control programmes for many agricultural field pests, especially those concerned with lepidopteran species (Schmutterer, 1985 and 1988).

The present study was aimed to evaluate : the insecticidal activity of some biorational insecticides, namely, ivomic, vertemic, agrothrin and neemix against cowpea beetle, $C$. maculatus and khapra beetle, T. granarium compared to actellic and malathion as chemical insecticides. The avian toxicity of the tested biorationals, neemix and ivomic against Japanese quail birds was also evaluated. To investigate these purposes three considerable bioassay methods, toxicity, antifeedant effect and residual toxicity were used as well as the toxicological and biochemical studies on Japanese quail birds.

\section{MATERIALS AND METHODS}

\section{Pesticides used :}

\subsection{Biopesticides :}

1.1.1 Abamectin :

Trade name : Vertimec 1.8\% EC

Producer : Novartis Agro., Swithzerland

\subsubsection{Ivermectin :}

Trade name : Ivomic $1 \%$ aq.

Producer : Merck Sharp \& Dohme BV, Harlem, Holland.

\subsubsection{Azadirachtin :}

Trade name : Neemix 4.5\% EC

Producer: Thermo Trilogy, Grace Drive, Columbia.

1.1.4. Pyrethrins (Natural) :

Trade name : Agrothrin $0.11 \% \mathrm{D}$

Producer : Agropharm Limited

\subsection{Chemical pesticides (Organophosphrus) :}

1.2.1. Malathion:

Trade name : Malason 1\% D

Producer : KZ, Egypt.

1.2.2. Pirimiphos methyl:

Trade name : Actellic 50\% EC

Producer : KZ, Egypt.

\section{Insects tested :}

The original strains of all tested insects were obtained from the Department of Stored-Product Pests, Plant protection Research Institute, Sakha branch, Agricultural Research Center, Dokki, Egypt. 
2.1. Cowpea beetle, Callosobruchus maculatus (F.) (Fam: Bruchidae):

Small glass jars containing $150-200$ unsexed adults and approximately 200 gm of cowpea seeds each were covered with muslin kept in position with rubber bands under laboratory conditions of $35^{\circ} \mathrm{C} ; \mathbf{7 0} \% \mathrm{RH}$. The cowpea seeds, Vigna unguiculate (L.), var. Azmerly, used for insect culture and experiments were previously sterilized by freezing at $-18^{\circ} \mathrm{C}$ for one week to kill any prior insect infestation, then stored in sealed polyethylene bags at $5^{\circ} \mathrm{C}$ until required for experiments. Newly emerged adults (0-24 hrs old) were used in the experiments. The culture medium was sieved to remove the old beetles therein and the emerged insects were collected for experiments.

\subsection{Khapra beetle, Trogoderma} granarium (Everts), (Fam. Dermestidae) :

Jars each contained 200-400 adults and $400 \mathrm{gm}$ of crushed wheat grain, Triticum aestivum var, Sakha 61 were covered with muslin cloth fixed with rubber bands to be tightly closed and maintained in the laboratory conditions of $35^{\circ} \mathrm{C} ; 70 \% \mathrm{RH}$. Newly emerged adults (0-24 hours old) were used in the experiments. The moisture contents of these grains were measured by ovendrying duplicate samples each of $5 \mathrm{gm}$, at $130^{\circ} \mathrm{C}$ for 1 hour, then calcualted from the following formula (according to ElZun, et al. 2012):

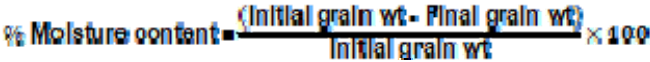

Cowpea seeds or wheat grains of moisture contents of 12.5 and $8.5 \%$, respectively were stored in sealed polyethylene bags in a refrigerator at $5^{\circ} \mathrm{C}$ till required for experiments.

\section{Test organism :}

Japanese quail birds, Coturnix coturnix Japonica were obtained from the flock bred by the Poultry Research Farm, Department of Poultry Production, Faculty of Agriculture, Kafr El-Sheikh, Tanta University. Birds were kept in metallic cages. Diet (Provided from the same source of birds) and water were offered ad-libitum. Initial average body weight of the birds was $120 \pm 15 \mathrm{gm}$. All birds were healthy and have never been subjected to any chemical contamination.

\section{Bioassay methods :}

\subsection{Toxicity to insects :}

Ten adults of both the tested insects or larvae of $T$. granarium were transferred to each treated dish by the tested materials. The same numbers of insects were transferred to petri-dishes containing grains treated with water only as control. Mortality counts were recorded 24 hour after treatment and corrected by Abbott's formula (1925). Concentration-mortality response lines were drawn. LC $_{50}$ and slope values were calculated according to the method of Finney, (1971).

\subsection{Residual toxicity assays :}

Lots each of $2 \mathrm{~kg}$ of wheat grains $(8.5 \%$ m.c.) or cowpea seeds $(12.5 \%$ m.c.) were treated with the tested insecticides. Each insecticide was diluted in water and added to the grains in which the final concentration would be equivalent to the $\mathrm{LC}_{99}$ of the insecticide against the tested insect . Jars were vigorously handshaken for adequate time to ensure complete mixing. The treated grains were allowed to dry at room temperature then packed in jute sacks $(20 \times 30 \mathrm{~cm})$ tightly closed and stored at room conditions (28 $\pm 2^{\circ} \mathrm{C}$ and $70 \pm 5 \%$ R.H.). Samples each of $20 \mathrm{gm}$ of treated grains were withdrawn at various periods (i.e. 1, 2, 4, 6, 8, 10 and 12 months) and placed in petri-dishes (9 cm diameter). Twenty adults of both insects or larvae of $T$. granarium (the $2^{\text {nd }}$ instar) of the tested insect were transformed to each dish for 24 hours, 
after which, mortality counts were recorded. Three replicates were made for each treatment. Time was plotted against mortality percentages on log-probit paper, and LT $_{50}$ values were calculated according to the statistical method of Finny 1971.

\subsection{Antifeedant effect of Azadirachtin:}

The antifeedant effect of Azadirachtin against larvae of khapra beetle, $T$. granarium, confined to wheat grains was evaluated. Two types of tests were carried out in this respect, choice and non-choice tests. In choice tests, a petridish (9 cm in diameter) was divided into two equal parts separated by simple barrier that allows insects to move freely from one part to the other. The first part received $20 \mathrm{gm}$ (about 350 grains) of treated grains, whereas the second one received $20 \mathrm{gm}$ of non-treated grains. A number of $\mathbf{5 0} \mathbf{2}^{\text {nd }}$ instar larvae were transferred to the treated portion. In nonchoice test the same procedure was conducted with dishes contained treated grains only. For both test, controls were made using non-treated grains. Four replicates were made for each treatment. Dishes were stored for 20 days under laboratory conditions, after-which percents of damaged grains were calculated.

\section{Toxicological effects on Japanese quail birds :}

\subsection{Acute toxicity :}

Acute toxicity of ivomic to Japanese quail birds expressed as $L D_{50}$ values and their fiducial limits was determined according to Weill (1952). Exploratory trials were performed in order to find out the smallest dose of each material that exhibits toxic effect to start with. The dose was multiplied by a constant factor and the produced dose was then multiplied by the same factor and so on to obtain four successive doses. Four groups of birds, each of three $(n=3)$ were used. Birds of each group were given orally doses. Doses were prepared in water and given to birds by means of a special syringe that has a needle equipped with a ball tip. Mortalities were recorded after 24 hours of treatment.

The $L_{50}$ values with confidence limits were calculated according to the following equation:

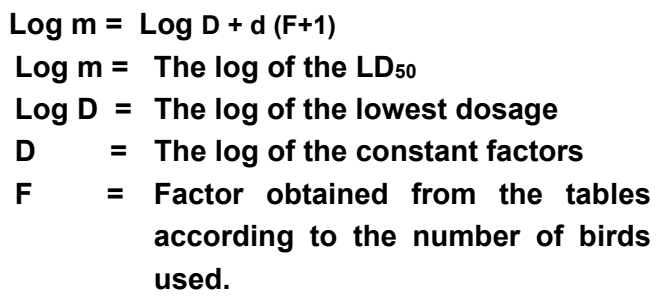
according to the number of birds used.

For the estimation of confidence limits, the following formula was used.

$$
\log m \pm 2 d \delta f
$$

$\delta f$ is obtained from the tables

\subsection{Short term- toxicity :}

Two groups of Japanese quail, each of 6 birds were used for oral toxicity tests of azadirachtin and ivomic. Birds of each group were orally given daily single doses for 21 consecutive days. Each dose was equivalent to $1 / 100$ or $1 / 500$ LD 50 . Doses were prepared in water, so a third group of birds was reserved as control and dosed water only. After the test period, birds were sacrificed, blood samples were collected, centrifuged at 4000/rpm for 10 minutes and serum samples were subjected to biochemical analysis. Livers were eviscerated, weighed and prepared for histopathological examination.

\subsubsection{Biochemical analysis:}

In serum of birds, biochemical parameters representing liver function were determined. In this respect, alanine aminotransferase, ALT (formerly, Glutamate pyruvate transaminase, GPT); alkaline phosphatase, ALP and total bilirubin were assayed. Assessments 
were done using an automated clinical chemistry analyzer at the Diagonistic Laboratory of Dr. Saleh El-Sharkawy, Prof. of Biotechnology, Faculty of Pharmacy, Mansoura University, Egypt. For ALT and ALP, Roche Diagonistic Kit (Manheim, Germany) were used, whereas Boehringer Kits (Manhiem, Germany) were used for determination of total bilirubin

\subsubsection{Oviposition :}

The number of eggs laid by females of birds were recorded after 21 days for treated and untreated birds and the reduction of eggs laid was calculated according as follows:

Reduction of eggs laid = [ ( No. eggs laid in control - No. eggs laid in treated ) I No. eggs laid of control ] x 100 (El-Zun, 1998).

\subsubsection{Histopathological examination :}

Tissue specimens of bird liver were fixed in $15 \%$ formalin saline, processed by dehydration in different concentrations of alcohols, cleared with xylol and embedded in paraffin blocks. Sections at $4 \mu$ thickness were made and stained by haematoxylin and eosine. Processing the tissues and preparing the slides were achieved by Dr. A.A. Menasi, professor of Pathology, Fac. of Medicine, Tanta Univ., Egypt., whereas, microscopic examination or reading these slides was done by Dr. A. AboRawash, Associate Prof. of Pathology, Fac. of Veterinary Medicine, Kafr ElSheikh, Tanta Univ., Egypt.

\section{RESULTS}

1. The acute toxicity of the tested insecticides against tested insects:

1.1. Toxicity after $24 \mathrm{hr}$. exposure :

The toxicity of the tested insecticides against the tested insects was evaluated using the technique of mixing with a feeding medium and results are recorded in Tables (1-3). On the basis of median lethal concentrations ( LC $_{50}$ values), the potency of the tested insecticides could be ranked descendingly as follows :

- Against adults of C. maculatus : Ivomic (a) $(0.19)>$ vertemic $^{\text {(a) }}(0.20)>$ agrothrin (b) $(0.40)>$ Pirimiphos-methyl (b) $(0.50)>$ malathion $^{(\mathrm{c})}$. (6.1).

- Against adults of $T$. granarium : Pirimiphos-methyl $(0.6)^{(a)}>$ vertemic $^{(b)}$ (1.2) > ivomic (c) (2.1) > agrothrin (c) (2.6) $>$ malathion $^{(d)}(5)$.

- Against larvae of T. granerium :

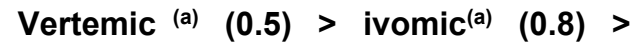
pirimiphos-methyl $\left.\right|^{(b)} \quad(13.3) \quad>$ malathion $^{(c)}(69.3)>$ agrothrin $^{(d)}(>352)$.

LC $_{50}$ values (in $\mathrm{mg}$ a.i./kg grains) are shown in parentheses. Based on the overlapped values of confidence limits, LC $_{50}$ values have the same letter have not significant differences. It is clear that avermectins (vertemic or ivomic) showed considerable toxicity to the tested insects that surpassed the toxicity of malathion or pirimiphos-methyl. However, Pirimiphos-methyl was the most toxic compound against the adults of khapra beetle, T. granarium followed by vertemic (Relative potentials for pirimiphos-methyl and vertemic : 100 and $50 \%$, respectively). According to the obtained LC $_{50}$ values, avermectins were nearly (30), (2-4) and (86-138 times) as toxic as malathion, against adults of $C$. maculatus, $T$. granasium and larval of $T$. granarium, respectively. Thus, from the acute toxicity point of view, ivomic might be regarded as promising stored grainprotectant that can replace malathion (taking into consideration their toxicological, environmental and economical variables). 
H.M. Elzun, et al.,

Table (1): Toxicity of the tested pesticides against adults of cowpea weevil, $C$. maculatus (F), after $24 \mathrm{hr}$. exposure to treated cowpea seeds

\begin{tabular}{|c|c|c|c|c|c|c|c|}
\hline \multirow{2}{*}{ Pesticide } & \multirow{2}{*}{ Formulation } & \multicolumn{2}{|c|}{$\begin{array}{c}\text { LC }_{50} \\
\text { (mg/kg seeds) }\end{array}$} & \multicolumn{2}{|c|}{$\begin{array}{c}\text { LC }_{99} \\
\text { (mg/kg seeds) }\end{array}$} & \multirow{2}{*}{ Slope } & \multirow{2}{*}{$\begin{array}{c}\text { Relative (1) } \\
\text { potency (\%) }\end{array}$} \\
\hline & & Value & $\begin{array}{l}\text { Fiducial } \\
\text { limits }\end{array}$ & Value & $\begin{array}{l}\text { Fiducial } \\
\text { limits }\end{array}$ & & \\
\hline Vertemic & EC & 0.20 & $0.17-0.29$ & 2.1 & $1.10-8.10$ & 2.3 & 95.00 \\
\hline Ivomic & $S L^{*}$ & 0.19 & $0.15-0.26$ & 2.2 & $1.10-8.70$ & 2.2 & 100.00 \\
\hline Agrothrin & $D^{* *}$ & 0.40 & $0.30-0.50$ & 2.5 & $1.50-8.90$ & 3.0 & 48.00 \\
\hline Malathion & $D^{* *}$ & 6.10 & $4.90-7.50$ & 36.3 & $23.4-80.5$ & 3.3 & 3.11 \\
\hline Pirimiphos-methyl & EC & 0.50 & $0.40-0.70$ & 4.9 & $2.90-12.6$ & 2.4 & 38.00 \\
\hline
\end{tabular}

* SL: Soluble liquid;

** D : Dust

(1) Relative potency $=\left(\mathrm{LC}_{50}\right.$ of the most toxic insecticide/LC 50 of the candidate insecticide $) \times 100$

Table (2): Toxicity of the tested pesticides against adults of khapra beetle, $T$. granarium Everts, after $24 \mathrm{hr}$. exposure to treated wheat grains

\begin{tabular}{|c|c|c|c|c|c|c|c|}
\hline \multirow{2}{*}{ Pesticide } & \multirow{2}{*}{ Formulation } & \multicolumn{2}{|c|}{$\begin{array}{c}\text { LC }_{50} \\
\text { (mg/kg seeds) }\end{array}$} & \multicolumn{2}{|c|}{$\begin{array}{c}\text { LC } 99 \\
\text { (mg/kg seeds) }\end{array}$} & \multirow{2}{*}{ Slope } & \multirow{2}{*}{$\begin{array}{c}\text { Relative (1) } \\
\text { potency } \\
(\%)\end{array}$} \\
\hline & & Value & $\begin{array}{l}\text { Fiducial } \\
\text { limits }\end{array}$ & Value & $\begin{array}{l}\text { Fiducial } \\
\text { limits }\end{array}$ & & \\
\hline Vertemic & EC & 1.2 & $0.9-1.6$ & 15.9 & $8.00-54.2$ & 2.1 & 50.0 \\
\hline Ivomic & $S L^{*}$ & 2.1 & $1.7-2.7$ & 17.8 & $10.2-51.4$ & 2.5 & 28.6 \\
\hline Agrothrin & $D^{* *}$ & 2.6 & $2.1-3.3$ & 17.2 & $10.5-41.7$ & 2.8 & 23.1 \\
\hline Malathion & $D^{* *}$ & 5.0 & $4.1-6.2$ & 24.0 & $15.7-51.9$ & 3.4 & 12.0 \\
\hline Pirimiphos-methyl & EC & 0.6 & $0.5-0.8$ & 5.40 & $3.10-13.7$ & 2.5 & 100.0 \\
\hline
\end{tabular}

* SL: Soluble liquid;

** D : Dust

(1) Relative potency $=\left(\mathrm{LC}_{50}\right.$ of the most toxic insecticide/LC 50 of the candidate insecticide $) \times 100$

Table (3): Toxicity of the tested pesticides against $2^{\text {nd }}$ instar larvae of khapra beetle, $T$. granarium Everts, after $24 \mathrm{hr}$. exposure to treated wheat grains

\begin{tabular}{|c|c|c|c|c|c|c|c|}
\hline \multirow{2}{*}{ Pesticide } & \multirow{2}{*}{ Formulation } & \multicolumn{2}{|c|}{$\begin{array}{c}\text { LC }_{50} \\
\text { (mg/kg seeds) }\end{array}$} & \multicolumn{2}{|c|}{$\begin{array}{c}\text { LC } 99 \\
\text { (mg/kg seeds) }\end{array}$} & \multirow{2}{*}{ Slope } & \multirow{2}{*}{$\begin{array}{c}\text { Relative (1) } \\
\text { potency } \\
(\%)\end{array}$} \\
\hline & & Value & $\begin{array}{l}\text { Fiducial } \\
\text { limits }\end{array}$ & Value & $\begin{array}{l}\text { Fiducial } \\
\text { limits }\end{array}$ & & \\
\hline Vertemic & EC & 0.50 & $0.4-0.6$ & 5.9 & $3.1-17.2$ & 2.1 & 100.00 \\
\hline Ivomic & $\mathrm{SL}^{*}$ & 0.80 & $0.7-1.1$ & 5.5 & $3.2-15.0$ & 2.9 & 62.50 \\
\hline Agrothrin & $D^{* *}$ & $>352$ & - & $>352$ & - & - & 0.14 \\
\hline Malathion & $D^{* *}$ & 69.3 & $56.9-85.5$ & 356.4 & $232.6-761.7$ & 3.3 & 0.72 \\
\hline Pirimiphos-methyl & EC & 13.3 & $10.8-18.7$ & 145.9 & $83.1-383.2$ & 2.3 & 3.80 \\
\hline
\end{tabular}

* SL: Soluble liquid;

** D : Dust

(1) Relative potency $=\left(\operatorname{LC}_{50}\right.$ of the most toxic insecticide/LC $\mathrm{C}_{50}$ of the candidate insecticide $) \times 100$. 


\subsection{The residual toxicity:}

The residual toxicity of the tested compounds was investigated. Insecticides-treated grains (at LC 99 's) were stored at laboratory conditions under complete darkness. Insects were exposed for $24 \mathrm{hr}$ to samples of treated grains, withdrawn at different periods of storage and mortality counts were recorded. Results were recorded in Table (4). In general, the tested compounds exhibited long residual effect (LT $50^{\prime}$ 's ranged 5.2 - 25.4 months). It was noted that, nearly, complete mortality was achieved for the tested insect exposed to treated grain within the first four months of storage, then the loss of the residual activity of insecticides over time seemed to be linear. Avermectins showed adequate residual toxic action currently required for effective protection against stored-grain insect $\left[\left(\mathrm{LT}_{50}:\right)(17.1,10\right.$ months) for vertemic and ivomic against adults of $C$. maculatus, respectively (Tables 4, 5 and 6).

Table (4): Residual toxicity of pesticides against adults of cowpea beetle, $C$. maculatus following, $24 \mathrm{hr}$. exposure to treated wheat grains, stored for different periods

\begin{tabular}{|l|c|c|c|c|c|c|c|c|c|c|}
\hline \multirow{2}{*}{ Pesticide } & \multirow{2}{*}{ Formulation } & \multicolumn{6}{|c|}{$\%$ Mortality at storage periods } & \multicolumn{2}{c|}{ LT $_{50}$ (months) } \\
\cline { 3 - 10 } & & 1 & 2 & 4 & 6 & 8 & 10 & 12 & Value & C. limits \\
\hline Vertemic & EC & 100 & 100 & 100 & 92 & 85 & 77 & 70 & 17.1 & $14.1-24.9$ \\
Ivomic & $\mathrm{SL}^{*}$ & 100 & 100 & 94 & 87 & 75 & 50 & 30 & 10.0 & $9.40-10.8$ \\
Agrothrin & $\mathrm{D}^{* *}$ & 100 & 100 & 100 & 100 & 100 & 90 & 80 & 15.7 & $13.7-24.6$ \\
Malathion & $\mathrm{D}^{* *}$ & 100 & 100 & 100 & 98 & 96 & 90 & 85 & 25.4 & $17.7-68.5$ \\
Pirimiphos-methyl & $\mathrm{EC}$ & 90 & 85 & 75 & 60 & 30 & 16 & 10 & 5.2 & $3.40-7.70$ \\
\hline
\end{tabular}

* SL: Soluble liquid

** D : Dust

Table (5): Residual toxicity of pesticides against adults of khapra beetle, T. granarium following, $24 \mathrm{hr}$. exposure to treated wheat grains, stored for different periods

\begin{tabular}{|l|c|c|c|c|c|c|c|c|c|c|}
\hline \multirow{2}{*}{ Pesticide } & \multirow{3}{*}{ Formulation } & \multicolumn{6}{|c|}{$\%$ Mortality at storage periods } & \multicolumn{2}{c|}{ LT $_{50}$ (months) } \\
\cline { 3 - 10 } & & 1 & 2 & 4 & 6 & 8 & 10 & 12 & Value & C. limits \\
\hline Vertemic & EC & 100 & 100 & 100 & 98 & 92 & 85 & 78 & 17.7 & $14.8-25.4$ \\
Ivomic & $\mathrm{SL}^{*}$ & 100 & 100 & 100 & 100 & 98 & 92 & 89 & 19.3 & $15.4-35.1$ \\
Agrothrin & $\mathrm{D}^{* *}$ & 100 & 100 & 100 & 95 & 83 & 70 & 52 & 12.9 & $11.8-18.0$ \\
Malathion & $\mathrm{D}^{* *}$ & 100 & 100 & 100 & 90 & 79 & 67 & 44 & 11.5 & $10.7-12.7$ \\
Pirimiphos-methyl & $\mathrm{EC}$ & 100 & 85 & 80 & 75 & 54 & 30 & 11 & 7.1 & $5.10-10.9$ \\
\hline
\end{tabular}

* SL: Soluble liquid

** D : Dust 
H.M. Elzun, et al.,

Table (6): Residual toxicity of pesticides against $2^{\text {nd }}$ instar larvae of khapra beetle, $T$. granarium following, $24 \mathrm{hr}$. exposure to treated wheat grains, stored for different periods

\begin{tabular}{|c|c|c|c|c|c|c|c|c|c|c|}
\hline \multirow{2}{*}{ Pesticide } & \multirow{2}{*}{ Formulation } & \multicolumn{4}{|c|}{ \% Mortality at storage periods (months) } & \multicolumn{3}{|c|}{ LT $_{50}$ (months) } \\
\cline { 3 - 10 } & & 1 & 2 & 4 & 6 & 8 & 10 & 12 & Value & C. limits \\
\hline Vertemic & EC & 100 & 100 & 93 & 87 & 66 & 45 & 31 & 9.6 & $8.90-10.4$ \\
Ivomic & $\mathrm{SL}^{*}$ & 100 & 100 & 100 & 89 & 75 & 67 & 46 & 11.6 & $10.7-12.9$ \\
Agrothrin & $\mathrm{D}^{* *}$ & - & - & - & - & - & - & - & - & -- \\
Malathion & $\mathrm{D}^{* *}$ & 100 & 100 & 100 & 100 & 95 & 90 & 81 & 17.2 & $14.5-25.8$ \\
Pirimiphos-methyl & EC & 100 & 100 & 100 & 100 & 95 & 80 & 70 & 15.2 & $13.0-22.0$ \\
\hline
\end{tabular}

* SL: Soluble liquid

** D : Dust

(-) Not teste

2. Antifeedant effects of Azadirachtin:

The antifeedant activity of azadirachtin against larvae of khapra beetle, $T$. granarium was evaluated. Two types of tests were performed, i.e. choice and non-choice tests. Larvae were confined to treated or non-treated wheat grains at petridishes for 20 days. Damaged grains was used as indicator to the antifeeding activity. Results, are recorded in Table (7) and Fig. (1). Results show that azadirachtin exerts a considerable antifeedant activity against the tested larvae. The effect was increasing with increasing the concentration of azadirachitin.

Azadirachitin at concentration, 500 $\mathrm{mg} / \mathrm{kg}$ grain completely prevented food consumption ( $\%$ of damaged grains was $(0.0,0.7)$ versus $(31.1,31.5)$ in control, for choice and non-choice tests, respectively). It is suggested that the concentration $30-125 \mathrm{mg} / \mathrm{kg}$ grain as an economic threshold for protecting grains against insect infestation.

\section{Toxicity to Japanese quail birds:}

\subsection{Acute-Toxicity:}

Acute oral toxicity of the formulated ivomic is shown in Table (8). $L D_{50}$ value is $255.86 \mathrm{mg} / \mathrm{kg}$ b.w. Eweis et al., (1995) found that $L_{50}$ of ivermectin to rats was $300 \mathrm{mg} / \mathrm{kg} \mathrm{b.w}$. Of course the value obtained herein greatly differs from that of technical material. However, for practical purposes the pesticide user is more interested in knowing the toxicity of the particular formulation he is using. Acute oral toxicity of Azadirachtin was found to be $>5000 \mathrm{mg} / \mathrm{kg}$ (Pesticide Manual, 2000). According to the tabulation of toxicity rating described by Hodgson and Levi (1997), the obtained $\mathrm{LD}_{50}$ value of Ivermectin could be categorized under the term very toxic and that of Azadirachtin "relatively nontoxic" according to Pesticide Manual, 2000. As a general guide, the probable lethal dose for an adult human weighing $\mathbf{8 0} \mathbf{~ k g ~ m a y}$ be derived from the acute oral $L_{50}$ for test animals (Oudejans, 1991). According to the following data reported by Campbell et al., (1983), Ivomic appears to have a very wide safety margin in target species. Cattle injected subcutaneously with a single dose of $6 \mathrm{mg} / \mathrm{kg}$ (30 times the recommended dose as a veterinary treatment) showed no signs of toxicity. Toxicity and death were recorded with $\mathbf{4 0}$ times the recommended dose. Dogs given a single oral dose of ivermectin showed no toxic signs at $10 \mathrm{mg} / \mathrm{kg}$; but death did not occur even at $20 \mathrm{mg} / \mathrm{kg}$, which is 20,000 times higher than the dosage needed to suppress the development of heartworm in dogs. 


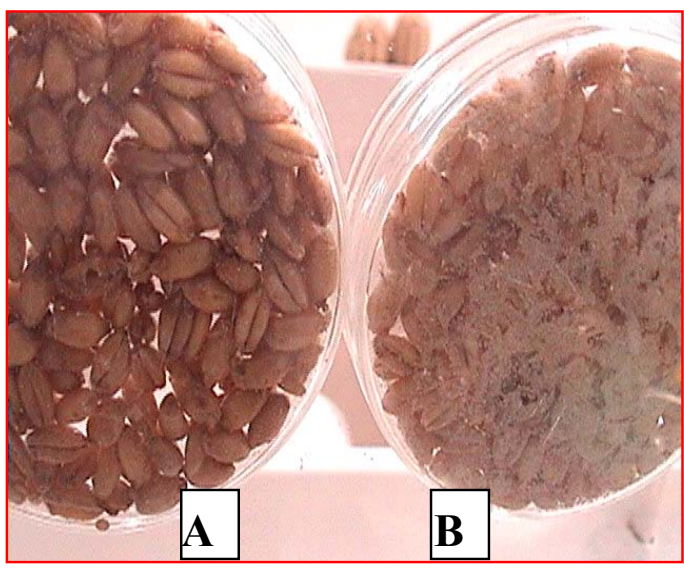

(I) Non-choice tests

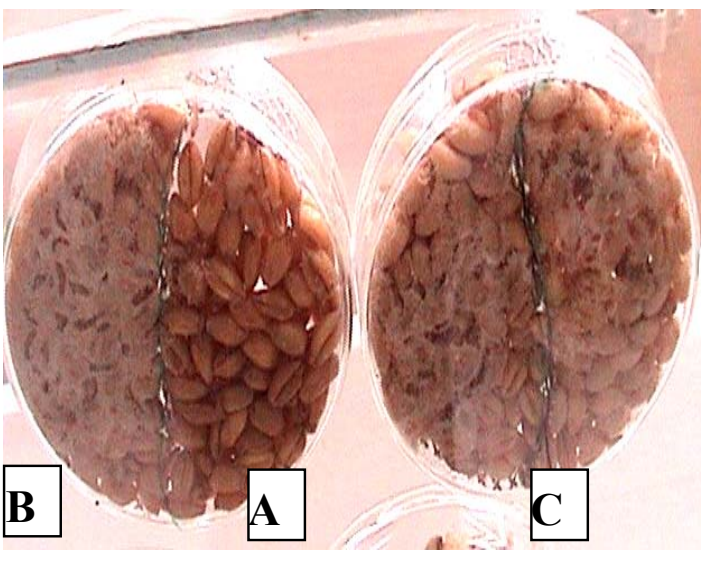

(II) choice tests

Fig. (1): Feeding deterrant effect of Azadirachtin as indicated by the degree of wheat grain damage caused by larvae of $T$. granasium

(A): treated grains (at $500 \mathrm{mg} / \mathrm{kg}$ grain).

(B), (C): untreated grains.

Table (7): Feeding deterrent effect of azadirachtin as indicated by the degree of wheat grains damage caused by larvae of khapra beetle, $T$. granarium after 20 days posttreatment

\begin{tabular}{|c|c|c|c|}
\hline \multirow{2}{*}{$\begin{array}{c}\text { Concentration } \\
\text { (mg/kg grains) }\end{array}$} & \multicolumn{3}{|c|}{ Damaged grains (\%) } \\
\cline { 2 - 4 } & \multicolumn{2}{|c|}{ Choice test } & Non-choice test \\
\cline { 2 - 4 } & Treated seeds & Non-treated seeds & Treated seeds \\
\hline 0.125 & $23.9 \mathrm{~b}$ & $29.4 \mathrm{ab}$ & $26.8 \mathrm{ab}$ \\
0.5 & $14.7 \mathrm{c}$ & $28.1 \mathrm{abc}$ & $12.8 \mathrm{c}$ \\
2 & $10.3 \mathrm{~d}$ & $27.2 \mathrm{abc}$ & $5.80 \mathrm{~d}$ \\
8 & $7.20 \mathrm{e}$ & $26.3 \mathrm{abc}$ & $5.10 \mathrm{~d}$ \\
30 & $4.70 \mathrm{f}$ & $25.6 \mathrm{bcd}$ & $4.20 \mathrm{~d}$ \\
125 & $1.90 \mathrm{~g}$ & $24.2 \mathrm{~cd}$ & $1.50 \mathrm{e}$ \\
500 & $0.00 \mathrm{~h}$ & $22.5 \mathrm{~d}$ & $0.70 \mathrm{f}$ \\
\hline Control & $31.7 \mathrm{a}$ & $31.1 \mathrm{a}$ & $31.5 \mathrm{a}$ \\
\hline
\end{tabular}

In the same column, values followed by a common letter are not significantly different.

Table (8): Acute toxicity of Ivermectin to Japanese quail birds

\begin{tabular}{|c|c|c|}
\hline Toxicant & LD $_{50}(\mathrm{mg} / \mathrm{kg}$ b.w $)$ & Fiducial limits \\
\hline Ivomic & 255.86 & $159.96-409.26$ \\
\hline
\end{tabular}




\subsection{Sub acute toxicity:}

The possible hepatotoxic effects of azadirachtin and ivomic on the Japanese quail birds were evaluated. Birds were orally treated with single repeated doses (each of $1 / 100$ or $1 / 500 \quad D_{50}$ ) for 21 consecutive days. Certain biochemical parameters representing liver function were assayed, in addition, liver tissues were histopathologically examined. Results recorded in Table (9) show that activities of ALT, alkaline phosphatase and total bilirubin in serum of birds treated with azadirachtin or ivomic, were significantly elevated. The effects were less powerful in ivomic-treated birds (e.g. Alkaline phosphatase activities were 340 , $215 \%$ of control for azadirachtin treatments, $1 / 100$ and $1 / 500$ LD $_{50}$, versus 170 and $126 \%$ of control for ivomic treatments, respectively).

Furthermore, ALT activity was not significantly affected in serum of Ivermectin-treated birds. The effects were generally, dose-dependent.

\subsection{Histological analysis:}

The results were ensured by the histopathologyical examination. The normal structure of liver of an untreated bird is shown in Fig. (2). Livers of birds treated with $1 / 100 \quad L_{50}$ of ivomic or azadirachtin showed hepatic toxicity indicated by histopathological alterations in their tissues. Tissues of those of ivomic showed inflammatory and necrotizing changes and bile ductproliferation (Fig. 3).

\subsection{Oviposition :}

It was obvious that all sublethal concentrations caused significant decrease in egg laying rates in a concentration dependent manner. Administration of concentration of $1 / 100$ and $1 / 500 L D_{50}$ led to severe reduction in egg laying rate by $75 \%$ and $65 \%$, respectively for azadirachtin and $60 \%$ and $35 \%$, respectively for ivomic, compared to the untreated control (Table 10).

Table (9): Effect of some pesticides on certain serum enzymes and biochemical parameters representing liver function of Japanese quail birds treated orally for 21 consecutive days.

\begin{tabular}{|c|c|c|c|c|c|c|c|c|}
\hline \multirow{2}{*}{ Pesticide } & \multirow{2}{*}{$\begin{array}{c}\text { Dose } \\
\text { (mg/kg } \\
\text { b.w) }\end{array}$} & \multirow{2}{*}{$\begin{array}{c}\text { Relative } \\
\text { liver weight } \\
(\mathrm{gm} / 100 \mathrm{gm} \\
\text { b.w) }\end{array}$} & \multicolumn{2}{|c|}{$\begin{array}{c}\text { ALT activity }{ }^{(1)} \\
\text { (U/L) }\end{array}$} & \multicolumn{2}{|c|}{$\begin{array}{c}\text { ALP activity }{ }^{(2)} \\
\text { (U/L) }\end{array}$} & \multicolumn{2}{|c|}{$\begin{array}{l}\text { Total bilirubin } \\
\text { (mg/100ml) }\end{array}$} \\
\hline & & & Mean & $\begin{array}{c}\% \text { of } \\
\text { control }\end{array}$ & Mean & $\begin{array}{c}\% \text { of } \\
\text { control }\end{array}$ & Mean & $\begin{array}{c}\% \text { of } \\
\text { control }\end{array}$ \\
\hline Azadirachtin* & $1 / 100$ LD 50 & $3.2 \mathrm{a}$ & $17 a$ & 270 & $2722 a$ & 340 & $0.13 b$ & 130 \\
\hline Azadirachtin* & $1 / 500$ LD $_{50}$ & $3.0 \mathrm{a}$ & $11.5 b$ & 183 & 1717 b & 215 & $0.12 \mathrm{c}$ & 120 \\
\hline Ivomic & $1 / 100$ LD $_{50}$ & $2.8 \mathrm{a}$ & $7.0 \mathrm{c}$ & 111 & $1358 \mathrm{c}$ & 170 & $0.14 \mathrm{a}$ & 140 \\
\hline Ivomic & $1 / 500$ LD 50 & $3.1 \mathrm{a}$ & $6.0 \mathrm{c}$ & 95 & $1007 d$ & 126 & $0.12 \mathrm{c}$ & 120 \\
\hline Control & - & $2.9 a$ & $6.3 \mathrm{c}$ & 100 & 800 e & 100 & $0.10 \mathrm{~d}$ & 100 \\
\hline
\end{tabular}

In the same column, values followed by a common letter are not significantly different.

(1) ALT, alanine aminatransferase, formerly GPT

(2) ALP, alkaline phosphatse

* $\mathrm{LD}_{50}$ of Azadirachtin was presumably considered to be $5000 \mathrm{mg} / \mathrm{kg} \mathrm{b.w}$. 


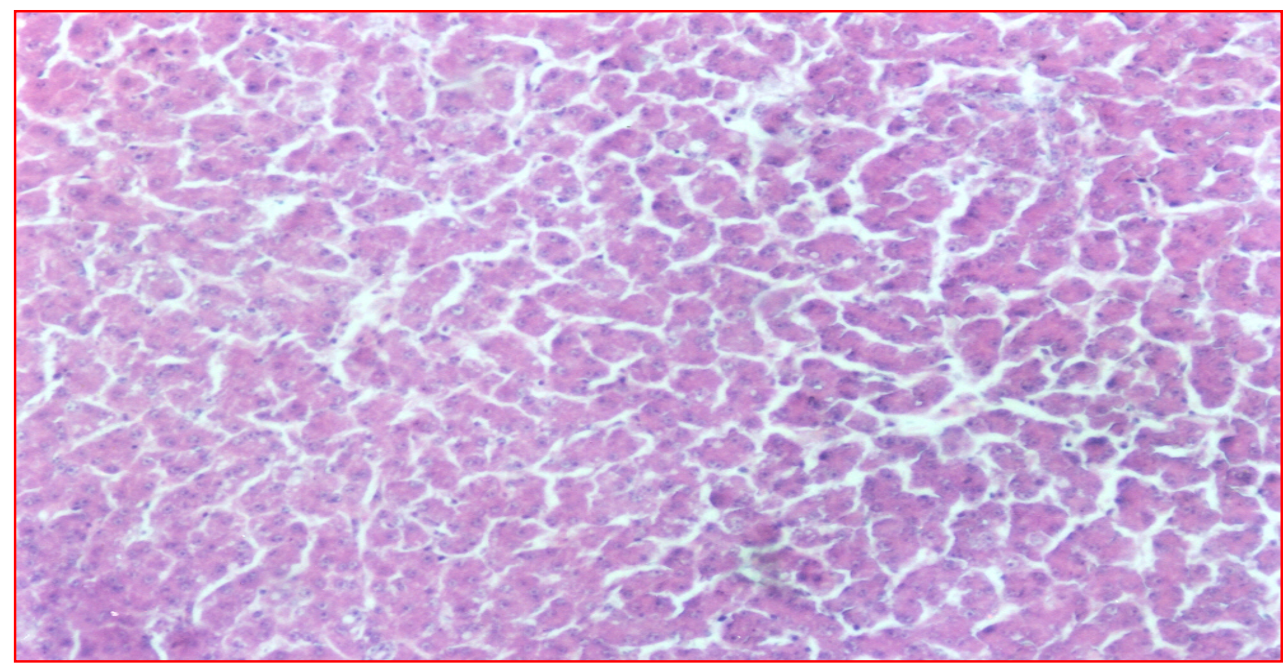

Fig. (2): Liver of control birds showing normal tissues (H\&E x200)

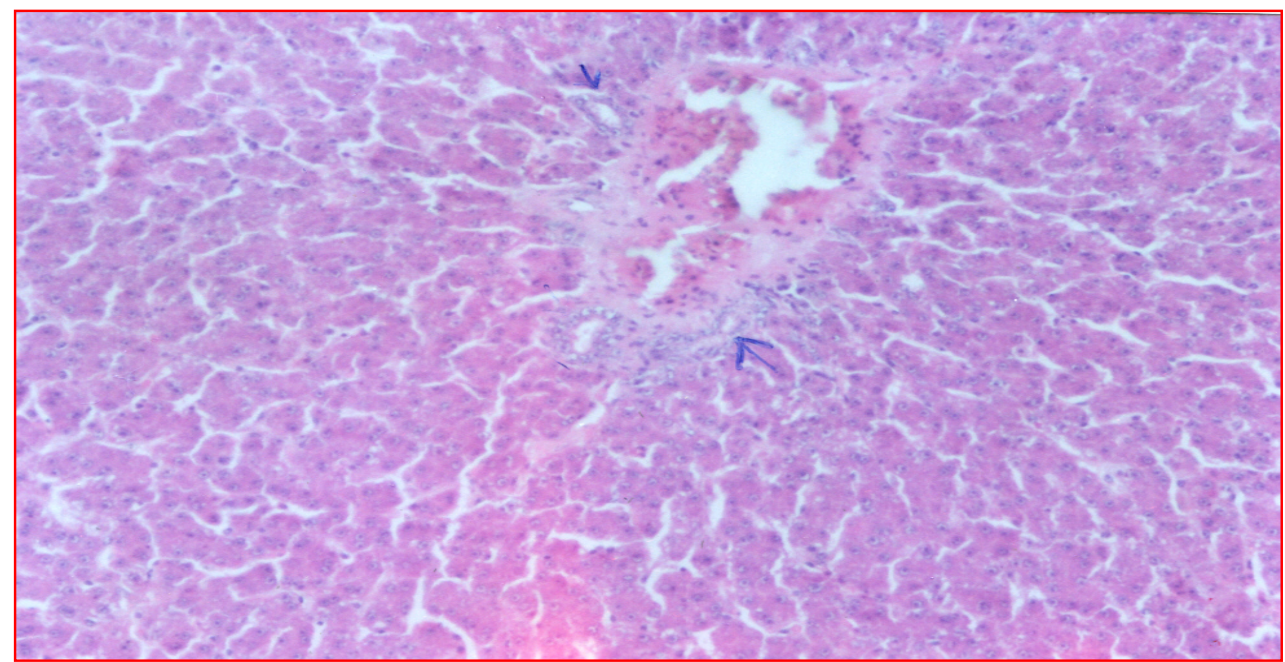

Fig. (3): Liver of birds treated with $1 / 100 L_{50}$ of Ivormic showing bile duct proliferation (H\&E×200)

Table (10): Effect of some pesticides on the eggs laid by Japanese quail birds.

\begin{tabular}{|l|c|c|c|}
\hline \multicolumn{1}{|c|}{ Pesticide } & $\begin{array}{c}\text { Dose } \\
\text { (mg/kg b.w) }\end{array}$ & $\begin{array}{c}\text { Number of egg laid/ } \\
\text { 3femal }\end{array}$ & $\begin{array}{c}\text { Reduction of eggs } \\
\text { laid(1) }\end{array}$ \\
\hline Azadirachtin* $^{*}$ & $1 / 100$ LD $_{50}$ & $17 \mathrm{~d}$ & $75 \%$ \\
Azadirachtin* & $1 / 500 \mathrm{LD}_{50}$ & $24 \mathrm{c}$ & $65 \%$ \\
Ivomic & $1 / 100 \mathrm{LD}_{50}$ & $27 \mathrm{c}$ & $60 \%$ \\
Ivomic & $1 / 500 \mathrm{LD}_{50}$ & $44 \mathrm{~b}$ & $35 \%$ \\
Control & - & $68 \mathrm{a}$ & $0 \%$ \\
\hline
\end{tabular}

In the same column, values followed by a common letter are not significantly different.

* LD 50 of Azadirachtin was presumably considered to be 5000 mg/kg b.w.

(1) Reduction of eggs laid = [ (No. eggs laid in control - No. eggs laid in treated / No. eggs laid in control) ] x 100 
Livers of azadirachtin-treated birds at $1 / 100 L_{50}$ showed hepatocellular necrosis, vacuolar degeneration and advanced fatty changes (Fig,s. 4,5). Through rough assumptions and calculations it could be concluded that quantities of grains consumed daily by human or livestock would carry residue levels of ivomic and azadirachtin that are much less than the tested levels required to manifest liver damage. Effective concentration needed to control insects on grains ranged 2-10 $\mathrm{mg} / \mathrm{kg}$ grain (as $\mathrm{LC}_{99}$ values) for ivomic, and $4 \mathrm{mg} / \mathrm{kg}$ grains for azadirachtin. Furthermore, washing of grain (a process known to be practiced before consumption), backing and cooking would make residues minimum on different foodstuffs.

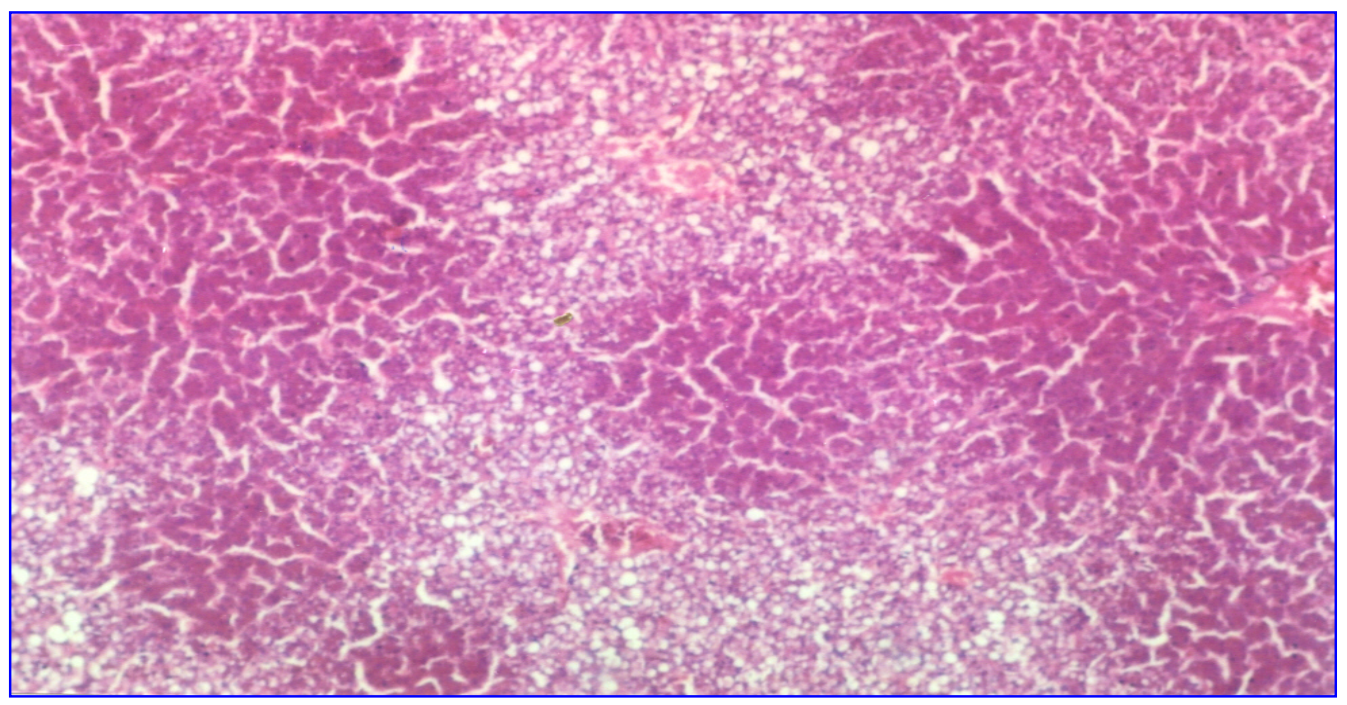

Fig. (4): Liver of azadirachtin treated birds (at $\left.1 / 100 L_{50}\right)$ showing centrolobular vacuolar degeneration and necrosis (H\&E×100).

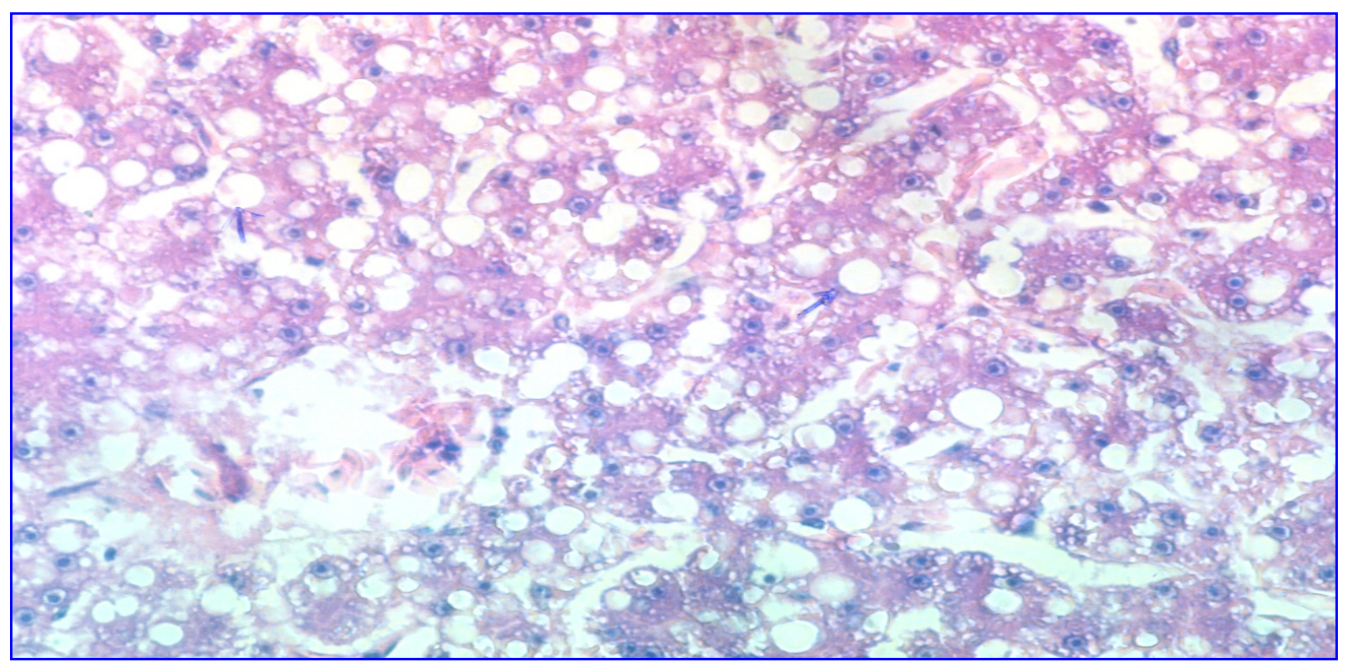

Fig. (5): Liver of azadirachtin treated birds (at $\left.1 / 100 L D_{50}\right)$ showing advanced fatty changes and necrosis (H\&E×400). 


\section{DISCUSSION}

The current study is an attempt to look for some alternatives to chemical synthetic insecticides. These alternatives might to be relativety safe on human, environment and have good affection against stored product insects. Three common assay methods: toxicity, resdual toxicity and antifeedant were used to evaluate four biocide agents, ivomic, vertemic, neemix and agrothrin against adults of $C$. maculatus, $T$. granarium and larval of $T$. granarium in compared to two standard chemical insecticides, malathion and actellic as referances. In addition neemix and ivomic were selected for example of biopesticides to study their side effects on Japanese quil birds through toxicological and hitopathological tests. The tested insecticides against the used insects showed that ivomic and vertemic showed considerable toxicity that surpassed the toxicity of Malathion or Pirimiphos-methyl based on the $\mathbf{L C}_{50}$ values. However, Pirimiphos-methyl was the most toxic compound against the adults of khapra beetle, $T$. granarium followed by vertemic (Relative potentials for pirimiphos-methyl and vertemic : 100 and $50 \%$, respectively). According to the obtained LC $_{50}$ values, avermectins were nearly (30), (2-4) and (86-138 times) as toxic as malathion, against adults of $C$. maculatus, T. granasium and larval of $T$. granarium, respectively. Thus, from the acute toxicity point of view, avermectins might be regarded as promising stored grain-protectant that can replace malathion (taking into consideration their toxicological, environmental and economical variables). The present findings are agreemnt with some previous studies. Malathion resistance in Tribolium castaneum was first reported in united states by Speirs et al., (1967) and Vincent and Lindgren (1967). Since that time many reports have shown that malathion resistance in this insect pest has grown in both scope and intensity (Haliday et al., 1988; Subramanyam et al., 1989 and Zettler and Cuperus, 1990). Although malathion could be considered as a standard insecticide for stored grain insects (Oudejans, 1991), the future status of malathion and pirimiphosmethyl, two organophosphate insecticides registered in the united states, is questionable because of registration procedures required by the Environmental Protection Agency (Arthur, 1994). Malathion is registered as a protectant of stored grains and most if not all labels will soon be with drown (Abramson, 1991). Pirimiphos-methyl is registered as a protectant for maize and sorghum, and these labels may also be amended (Arthur, 1994). However, malathion $D(1 \%)$ is recommended by Ministry of Agriculture in Egypt to be mixed with stored grains as a protectant against their insects (Anonymous, 2001). The obtained results revealed also that pyrethrins (Agrothrin 0.11\% D) exhibited reasonable toxicity to the tested insect (relative potencies were $48 \%$ versus $3.11 \%$ for malathion). The result is consistent with that of GouameneLamine et al., (2003) who found that adults of susceptible strain of the chlorado beetle, Leptinotarse decemlineata (Say) were less sensitive to the toxic action of abamectin and two of its analogs when compared to susceptible larval stages. Agrothrin gave effective grain protection against Sitophlus zeamais, it caused mortalities more than $95 \%$ of insects after 5 and 6 weeks (Hategekimana, 2017). The authors concluded that abamectin resistance in chlorado beetles was due mainly to enhanced oxidative metabolism of abamectin. Phyrethrum has been in general use for many years, but supplies are limited and so to seduce the cost and extend its usefulness, low concentrations 
of pyrethrins are mixed with a synergist (often, piperonyl butoxide) which enhances their activity. Pyrethrins like all members of the pyrethroid insecticide family, kill insects by disputing their nervous systems. Pyrethrins are toxic to the "sodium channel" of the cellular structure that allows sodium ions to enter a cell as part of the process of transmitting a nerve impulse. This leads to repetitive discharges by the nerve cell which causes paralysis and death (Crosby, 1995).

The tested compounds exihbited long residual effect $\left(L_{50}\right)_{s}$ ranged from 5.225.4 months. Within the the first four months of storage completely mortality was achieved for the tested insects then the loss of the residual activity of insecticides started to reduce overtime. Beeman and Speris (1986) studied the residual toxicity of abamectin on wheat treated with the initial concentration, 10160 p.p.b against adults of three species of caleoptera. They found that the halflife for decay of biological activity of the compound was 3-6 months. Abo-Arab and El-Hamady (1998) found that the residual toxicity of ivermectin on grains (wheat or cowpeas) treated at $\mathrm{LC}_{99}$, effectively lasted for 3-9 months against adults of $S$. oryzae and $C$. maculatus. The varations in duration of residual toxicity might be due to differences in the initial concentration of the toxicant on grains leading to varied half life values. Thus, loss of activity of avermectins on treated grains is not assumed to follow first order reaction. For any given first order reaction half-live $\left(\mathrm{t}_{0.5}\right)$ is a constant and independent of the initial concentration (Glasstone and Lewis (1968). From results obtained, it was obvious that pyrethrins mixed with grains showed long residual effect ( $\mathrm{LT}_{50}$ values: 15.7 months, against adults of $C$. maculatus (Table 4). Pyrethrins are known to have very short halflives, but the long residual effect observed in the present study might be due to the indoor conditions, in particular, the complete darkness in which the treated grains were stored. Outdoors, pyrethrins persist only for a short time. For example, after application of pyrethrins to bare soil, the half life was two hours or less (WHO and FAO, 2000). Pyrethrins persist much longer indoors than they do outdoors. Berger-prei B et al., (1997) found that pyrethrins persisted in carpet dust for over two months after treatment. A large family of insecticides, the synthetic pyrethroids, are structurally similar to pyrethrins but have been chemically modified to make them more toxic and more persistent. Pyrethrin insecticides often contain piperonyl butoxide, a chemical that increases their potency. The synergized pyrethrins were recommended for controlling the confused flour beetle, Triboluim castaneum du Val., a major insect of flour mills, processing plants and indoor food warehouses (Arthur, 1998). Several pyrethroids applied in combination with piperonyl butoxide synergist have been evaluated as protectants of wheat stored (Bengston, et al., 1980 a). Synergised pyrethrin aerosals have been used in pest control programs against stored product insects at mills and processing plants in the USA but the piperonyl butoxide synergist used in pyrethrin formulations it's was currently under review by the U.S. Environmental Protection Agency (Arthur, 1998). Biebel et al., (2003) reported that, pyrethrum extract has a long history of successful application in the control of stored products. Its low environmental hazard makes it an ideal pesticide for outdoor pre-harvest treatment. However, the disadvantages of its low light stability then becomes apparent. This drawback can be overcome by the combination of pyrethrum extract with $\delta$ cyclodextrin. To slow down the quick metabolism of pyrethrum by the insect microsomal system synergistic substances were 
added. Additional to the already wellknown piperonyl butoxide, two natural synergis, sesamol and tocopherol acetate were combined with pyrethrum extract and found to enhance the toxicity. storage conditions, i.e. temperature and moisture content can also affect the stability of pyrethrins. Noble et al., (1982) reported that permethrin treated wheat and stored at $25^{\circ} \mathrm{C}(12 \%$ moisture) or $35^{\circ} \mathrm{C}(15 \%$ moisture) had a half-life of 252 and 44 weeks, respectively. The half-life, being dependent on the wheat storage conditions, decreased as the temperature and moisture increased.

The conventional insecticides, malathion and pirimiphos-methyl showed also, long residual toxicity. The duration of the residual toxic action of pirimiphosmethyl was shorter than that of malathion particularly against adults of $C$. maculatus and $T$. granarium (LT 50 values: 5.2 and 7.1 ) months versus 25.4 and $\mathbf{1 1 . 5}$ months for malathion against $C$. maculatus and $T$. granarium, respectively, (Tables 4,5). Abo-Elghar et al., (2003) found that pirimiphos-methyl applied at $25 \mathrm{mg}$ a.i./kg cowpea seeds showed residual activity against $C$. maculatus extended up to 8 months posttreatment. Also, pirimiphos-methyl gave nearly $100 \%$ control of adults of $T$. castaneum (confined to treated wheat grain) for 9 months at $4 \mathrm{ppm}$ and 11 months at 8 ppm (White, 1984).

Azadirachtin (neemix) was evaluated against larvae of $T$. granarium using choice and non-choice technique.Neemix exert vigour antifeedant activity aginst the testd larvae. Similarly, Muda and Cribb (1999) found that the antifeedant effect of azadirachtin on adults of Rhyzopertha dominica was effected when provided that $50 \%$ of the wheat grain was treated with an effective level of azadirachtin. Jilani and Saxena (1990) reported that neem compounds were too complex to be synthesized for practical purposes. A significant reduction of food consumed by the $4^{\text {th }}$ and $6^{\text {th }}$ instar larvae of of the Spodoptera littoralis were treated with sublethal concentrations of Nimbecidine (0.03\% Azadirachtin) (Ghoneim and Hamadah,2017).

Azadrachtin was originally isolated owing to its outstanding antifeedant effect against the desert locust, Schistocerca gregaria and this finding ushered in the concept of non-toxic crop protectants based on feeding deterrence (Isman, 1994). Azadirachtin and Azadirachtin-based insecticides were also found to be antifeedant effect on coleopteran and lepidopteran insect species infesting stored-products (Jilani and Saxena 1990; Gerard and Ruf 1995; Muda and Cribb 1999). The repellent effects of these insecticides against coleopteran species were demonstrated as well (Jilani and Mali 1973; Jilani and Saxena 1990; Ban et al., 2000; Kayode and Adanlawa, 2002).

Certin biochemical parametar representing liver function were assayed in along with histopathlogically examinations. Results obtained showed that activities of tested enzymes and bilirubin serum of birds tested with neemix and ivomic were significantly elevated. These results were ensured by histopathological examination which showed hepatic toxicity. Wilkinson, (1970) reports that GPT (ALT) is more specific indicator for liver damage and bilirubin is of particular interest in quantifying hepatic damage (Hayes 1989). Eweis et al. (1995) found that plasma of rats received ivermectin in drinking water for 4 weeks, at concentrations equivalent to $(0.1-0.5)$ LD $_{50}$ showed affected levels of GOT and GPT. According to Burtis and Edward (1994), tests of hepatic function include those of hepatic synthetic function (e.g. determination of albumin), metabolic function (e.g determination of bilirubin) 
and excretory function (e.g. determination of substances released from damaged tissues such as GOT, GPT and alkaline phosphate). The possible mechanism involved in the elevation of transaminases e.g. GLT may be due to tissue damage (Korsrud et al., 1972). The activity of hepatic enzymes e.g. GLT and alkaline phosphatase released in the blood by the damaged liver is one of the most useful tools in the study of hepatotoxicity (Hayes, 1989). Hence, liver function impairment of treated japanese birds might be induced. Ivermectin (Ivomic) caused hepatic damaged and an altered liver enzyme, as well as, histopathological changes in liver has been noticed, while vitamin $\mathrm{C}$ show ameliorative to the toxic effect of ivermectin positively (AL-jassim et al 2015). Ivermectin caused cleft palates in mice and rats at oral doses of 0.4 and $\mathbf{1 0}$ $\mathrm{mg} / \mathrm{kg} /$ day respectively, and cleft palates and clubbed feet in rabbits dosed at 3 $\mathrm{mg} / \mathrm{kg} /$ day (Kirkland, 2018). The results of study demonstrate that subchronic oral administration of abamectin altered some biochemical parameters which correlated with histopathological changes (Abd-Elhady and Abou-Elghar 2013). The repeated administration of Ivermectin injection formulation at five times the recommended dose is fatal to donkeys (Ismail et al., 2013).

FAO, (1995) reports: a dose of 0.12 $\mathrm{mg} / \mathrm{kg} \mathrm{b.w}$. of abamectin per day to rats (two generations study of reproductive toxicity) is the level that cause no toxic effect. Metabolism may be one of many factors responsible for the low mammalian toxicity of avermectins at the concentrations needed to kill arthropodes. Abamectin and Ivermectin were found to be metabolized by rat liver microsomes (Zeng et al., 1996b). The compounds and their metabolites are excreted mainly in the feces and they do not readily more from the site of dung deposition because of their low solubility in water and their binding to organic matter (Wratten and Forbes 1996). Balligar et al, (2014) study the effect of azadirachtin on the liver function in rats, they found decrease in total protein and albumin levels, whereas a significant increase in BUN, AST, ALT, and ALP levels were noticed compared with the control.

The results obtained showed that the concentration of $1 / 100$ and $1 / 500 L_{50}$ caused significant decrease in egg laying rates for adult Japanese quail (Coturnix coturnix japonica) for 21 days. This result was agreement with (El-Zun et al., 2016), they found the adult of Japanese quail (Coturnix coturnix japonica) treated with Pirimiphos-methyl levels of $1 / 10,1 / 100$ and $1 / 1000 L_{50}$, for 21 days at dietary caused significant reduction by 58.6 and $44.8 \%$ at $1 / 10$ and $1 / 100 L_{50}$, respectively.

\section{REFERENCES}

Abbott, W.S. (1925). Method for computing the effectiveness of insecticides. J. Econ. Entomol, 18 (2): 265-273.

Abd-Elhady, H.K. and G. E. Abou-Elghar (2013). Abamectin Induced Biochemichal and Histopathological Changes in the Albino Rat, Rattus norvegicus. J. of Plant Protection Res. 53: (3), 263-270.

Abo-Arab, R.B.S. and Sh. E.E. El-Hamady (1998). Ivermectin: as a protectant against stored grain insects. Alex. Sci. Exch. 19:49-427.

Abo-Elghar, G.E., A.E. El-Sheikh, F.M. ElSayed, H.M. El-Maghraby and H.M. EIZun (2003). Persistence and residual activity of an organophosphate, pirimiphos-methyl, and three IGRs, hexaflumuron, teflubenzuron and pyriproxyfen, against the cowpea weevil, Callosobruchus maculatus (Coleoptera : Bruchidae).Pest-Manag. Sci. 6: 95-102. 
Abramson, A.S. (1991). Malathion, deletion of certain uses and directions for use. Fed. Reg. 56, 11419-11420.

AL-Jassim, K. B., A.H. Jawad, E.A. ALmasoudi and S. J. Khadim (2015). Biochemical and Histological Alterationsinthe Liver due to Repeated Administration of Ivermectin alone or with Combination of Vitamin $\mathrm{C}$ in Local Female Rabbits. J. of International Academic Res. For Multidiciplinary. 3: (7), 349-364.

Anonymous (2001). Technical Recommendations for protection of Agricultural pests. Ministry of agriculture and Land Reclamation, Egypt. P. 230

Arthur, F.H. (1994). Efficacy of Unsynergised Deltamethrin + Chlorpyrifos-methyl combinations as protectants of stored wheat and stored corn (maize). J. Stored prod. Res. Vol. 30, No. 1 , PP. 87-94.

Arthur, F.H. (1998). Residual toxicity of cyfluthrin wettable powder against Tribolium confusum (Coleoptera : Tenebronidae) exposed for short time intervals on cocrete. J. stored prod. Res. Vol. 34 No. 1, PP. 19-25.

Atwal, A.S. (1976). Agricultural pests of indian and South-East. Kolyani, Ludhiana.

Baligar, N.S., R.H. Aladakatti, M. Ahmed and M.B. Hiremath (2014). Hepatoprotective activity of the neembased constituent azadirachtin-A in carbon tetrachloride intoxicated Wistar rats. Canadian J. of Physi. and Pharmacology, 92(4): 267-277.

Ban, U., A.K. Shahanara and L. Takao (2000). The efficacy of volatile ingredients in neem oil against Callosobruchus chinensis (Coleoptera : Bruchidae). Kagwa Daigaku Nogakubu Gakayutsu okoku. 52: 6769.

Benbrook, C. M. (1991). Sustainable Agriculture Research and Education in the Field,. National Academy Press. Washington, DC.

Beeman, R.W. and W.E. Speirs (1986). Toxicity, persistence and antagonism of avermectin $b_{1}$ against stored products insects. Proc. of the Third. International-Working Con. on Stored Product Entomology, October 23-28, 1983, Kansas State Univ., Monhattan Kansas USA 1984 recd 1986; 246-255.

Bengston, M., M. Connell, R.A. Davies, J.M. Desmarcheller, W.B. Elder, R.J. Hart, M.P. Phillips, E.G. Ridley, B.E. Ripp, J.T. Snelson and R. Sticka (1980a). Chlorpyripos-methyl plus bioresmethrin, metacrifos, pirimiphosmethyl plus bioresmethrin and synergized bioresmethrin as grain protectants for wheat. Pestic. Sci. 11, 61-76.

Berger-PreiB, E., E.K. Levssen and A. PreiB (1997). Analysis of individual natural pyrethrins in indoor matrices by HRG/ECD. J. High Resol. Chromatogr. 20 : 284-289.

Biebel, R., E. Rametzhofer, H. Klapal, D. Polheim and H. Viernstein (2003). Action of pyrethrum based formulations against grain weevils. International Journal of pharmaceutics (kidlington). 256 : 175181.

Burg, R.W. and E.O. Stapley (1989). Isolation and characterization of the producing organism. In ivermectin and avermection: Campell, W.C.; Ed.; Springer Verlag : New York, 1989: pp 24-32.

Burtis, C. and A. Edward (1994). Clinical chemistry $2^{\text {nd }}$ Vol. 2, Saunders Company. Printed in USA.

Campbell, W.C., H. Fisher, E.O. Stapley, G. Albers-Shonberg and T.A. Jacob (1983). Ivermectin : A potent new antiparasitic agent. Science. Vol. 221. PP. 823-831.

Chaudhary, S., R.K. Kanwar, A. Sehgal, D.M. Cahill, C.J. Barrow, R. Sehgal and 
J.R. Kanwar1 (2017). Progress on Azadirachta indica Based Biopesticides in Replacing Synthetic Toxic Pesticides. Front Plant Sci.; 8:610.

Crosby, D.G. (1995). Environmental fate of pyrethrins In pyrethrum flowers : production, Chemistry, toxicology, and uses. J. E. Casida and G.B. Quistad New York Ny Oxiford University press. PP. 177-178.

El-Zun, H.M.M. (1998). Comparative Studies on the effectiveness of some plant extracts and insect growth regulators against the cowpea weevil, Callosobruchus maculatus (F.). M.Sc., Menoufiya Univ.

El-Zun, H.M., G.E. Abouelghar, H.S. Radwan and A.F. Omer (2016). Sublethal toxic effects induced by Pirimiphos-methyl in the japanese quail (Coturnix coturnix japonica). J. Plant Prot. and Path., Mansoura Univ. 7(9): 573-578.

El-Zun, H.M., N.A. El-Aidy and E.A.I. Mohamed (2012). Effect of microwave energy on cowpea beetle (Callosobruchus maculates Fabricius.), some chemical contents and viability of cowpea seeds Egypt. J. Agric. Res., 90(2): 4560.

Eweis, E.A., N. Elhwashy, H.K. Said and M.A. Kandil (1995). Acute toxicity of ivermectin in laboratory animils $1^{\text {st }}$, Int. Conf. of Pest control, Mansoura, Egypt, Sept. 1995: 86-89.

FAO (1995). Pesticide residues in food, plant production and protection paper. 133. Geneva, Switzerland.

Finney, D.J. (1971). Probit Analysis. Cambridge. Univ. Press. PP 333.

Fisher, M.H. and H. Mrozik (1989). Chemistry In Ivermectin and avermectin; Campbell, W.C. Ed.; Springer-Verlag: New York, 1989; PP 1-23.
Gerard, P.J. and L. Ruf (1995). Effect of a neem (Azadirachta indica A. Juss, Meliaceae) extract on survival and feeding of larvae of four keratinophagous insects. J. Stored Prod. Res. 31: 111-116.

Glasstone, S. and D. Lewis (1968). Elements of physical chemistry. $2^{\text {nd }}$ London, Macmilian \& Co. LTD.

Ghoneim and Hamadah, (2017). Antifeedant activity and detrimental effect of Nimacidine $(0.03 \%$ Azadirachtin) the nutritional performance of Egyptian cotton leafworm Spodoptera littoralis Boisd.(Noctuidae: Lepidoptera). Bio Bulletin, 3(1):39-55.

Gouamane-Lamine, C.N., K.S. Yoon and J.M. Clark (2003). Differential susceptibility to abamectin and two bioactive avermectin analoges in abamectin resistant and susceptible strains of Colorado potato beetle, Leptinotarsa decemlineata (Say) (Coleoptera : Chrysomelidae). Pesticide -Biochemisty and Physiology. 76: 15-23.

Haliday, W.R., F.H. Arthur and J. Zettler (1988). Resistance status of red flour beetle (Coleoptera : Tenebrionidae) infesting stored peanuts in the south eastern united states. J. Econ. Entomol 81: 74-77.

Hategekimana, A. (2017). Insecticidal and grain-protecting properties of a pyrethrum-based product against stored maize weevil, sitophilus zeamais (Coleoptera: Curculionidae). Fresenius Environmental Bulletin, 26(8):5136-5141.

Hayes, A.W. (1989). Principles and methods of toxicology. Raven press. New York $2^{\text {nd }}$ ed.

Hodgson, E.A and P.E. Levi (1997). Modern toxicology. Appleton \& Larrge. Printed in USA. P. 239.

Ismail, N.H.A., S.E. Suliman, A.G.A. Bulldan and H.I. Seri (2013). 
Haematological, biochemical and histopathological alteration induce by Ivermectin in donkeys (Equusasinus). Sudan J. Sci. Tech. 14(2):1-14.

Isman, M.B. (1994). Botanical insecticides. Pesticide outlook, June, P: 26-30.

Jackai, L.E.S. and R.A. Daoust (1986). Insect pests of cowpea. Annu. Rev. Entomol., 31: 95-119.

Jilani, G. and M. Malik (1973). Studies on neem plant as a repellent against stored grain insects. J.Sci. Ind. Res. 16: 251-254.

Jilani, G. and G. Saxena (1990). Repllent and feeding deterrent effects of turmeric oil, sweetflag oil, neem oil, and a neem based insecticide against lesser grain borer (Coleoptera : Bostrchidae). J. Econ, Entomol. 88 : 628-680.

Kayode, J. and I. G. Adanlawo (2002). Pesticidal potentials of Azadirachta indica and Gmelina arborea on cowpea weevil (Callosobruchus maculatus). Journal of Tropical forest Products. 8 : 130-134.

Kirkland, Q.C. (2018). Product monograph (ivermectin tablets) including patient medication information.

https://www.merck.ca/static/pdf/STRO MECTOL-PM_E.pdf

Koehler, P. G. (2003). Management of stored grain and peanut pests. University of Florida IFAS, Extension. Electronic puplications.

Korsrud, G.O., H.C. Grice and J.M. Mclaughan (1972). Sensitivity of several serum enzymes in detecting carbon tetrachloride. liver damage in rats. Toxicol. Appl. pharmacol. 22: 474-483.

Miller, T., L. Chaiet, D. Cole and L. Cole (1979). Antimicrob. Agents. Chemother. 15: 369-469.
Muda, R. and B.W. Cribb (1999). Effect of uneven application of azadirachtin on reproductive and anti-feedant behaviour of Rhyzopertha dominica (Coleoptera :Bostrichidae). Pestic. Sci. 55 : 983-987.

Noble, P.M., D.J. Hamilton and W.J. Obsborne (1982). Stability of pyrethroids on wheat in storage. Pestic. Sci. 13, 246-252.

Oudejans, J.H. (1991). Agro-pesticides, properties and functions in integrated crop protection. United Nations, Bangkok, $4^{\text {th }}$ ed.

Pesticide Manual (2000). The pesticide Manual $12^{\text {th }}$ ed. The British Crop Protection Council.

Righi-Assia, A.F., M.A. Khelil, F. Medjdoub-Bebsad and K. Righi (2010). Efficacy of oils and powders of medicinal plants in biological control of the pea weevle (Callosobruchus chinensis L. ). Afr. J. Agri. Res. 5(12): 1474-1481.

Salonkhe, D. K., J.K. Chiavan and S.S. Kadam (1985). Postharvest biotechnology of cereals, CR, C Press, Boca, Raton, FI.

Schmutterer, H. (1985). Which insect pest can be controlled by application of neem seed kernel extracts under field conditions ? Z. Angew Ent. 100, 468 475.

Schmutterer, H. (1988). Potential of azadirachtin containing pesticides for integrated pest control in develoing and industrialized countries. J. Insect physiol. 7, 713-719.

Shoop, W.L., H. Mrozik and M.H. Fisher (1995). Structure and activity of avermectin and milbenycin in animal health. Vet. Parasitol, 59: 139-156.

Speirs, R.D., L.M. Redlinger and H.P. Boles (1967). Malathion resistance in the red flour beetle. J. Econ. Entomol. 60: 1373-1374. 
Subramanyam, B., P.K. Harein and Cutkomp (1989). Organophosphate resistance in adults of red flour beetle (Coleoptera : Cucuidae) infesting barley stored on farms in Minnesota J. Econ. Entomol. 82 : 989-995.

Vilyoen, J.H. (1990). The occurance of Trogoderma granarium (Coleoptera: Dermestidae and related species is Soithern Africa with special reference to $T$. granarium and its potential to become established. J. of Stored Prod. Reseach, 26: 43-51.

Vincent, L.E. and Lindgren (1967). Susceptibility of laboratory and fieldcollected cultures of the confused flour beetle and red flour beetle to malathion and pyrethrins. J. Econ. Entomol. 60: 1763-1764.

Wehner, T., J. Lasota and R. Demchak (1993). In comprehensive Analytical Profiles of Important pesticides, ed. J. Sherma and T. Carins. CRC Press. Boca Raton, Florids, 1993. Ch4: pp. 73-106.

Weill, C.S. (1952). Tables for convenient calculation of medium effective dose $\left(L_{50}\right.$ or $E D_{50}$ and instructions in their use. Biometrics 8 : 249-263.

White, N.D.G. (1984). Residual activity of organo-phosphorus and pyrethroid insecticides applied to wheat stored under simulated western canadian conditions. Canadian-Entomolos 116 (10): 1403-1410.

WHO and FAO (2000). Pesticide residues in food. 2000 evaluations. Part 1. Residues. FAO plant production and protection paper 165 . 700.

Wilkinson, J.H. (1970). Cinical significance of enzyme activity measurements. Clin. chem. 16, 882.

Wratten, S. D. and A.B. Forbes (1996). Environmental assessment of veterinary avermectines in temperate pastoral ecosystems. Anals of Applied Biology, 128: 2.

Zeng, Z., N.W. Andrew, J.M. Woda, B.A. Malley, I.S. Crouch and R.W. Wang (1996b). Role of cytochrome P 450 isoforms in the metabolism of Abamectin and ivermectin in rats. J. Agric. Food Chem. 44: 3374-3378.

Zettler, J.L. and G.W. Cuperus (1990). Pesticide resistance in Tribolium castaneum (Coleoptera : Tenebrionidae) and Rhyzopertha dominica (Coleoptera : Bosonidae) in wheat. J. Econ. Entomol. 83: 16771651. 


\section{النشاط الإبادي لبعض المبيدات الكيماوية والحيوية المنتخبة ضد خنفساء اللوبيا وخنفساء

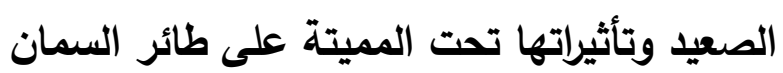

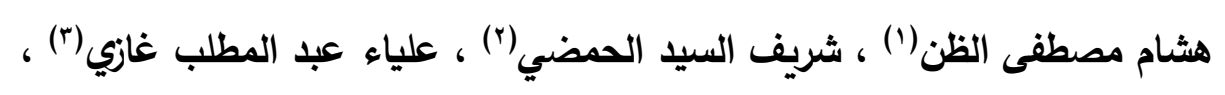

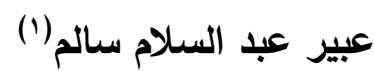

(1) قسم بحوث آفات الحبوب والمواد المخزونة - معهل بحوث وقاية النباتات - مركز البحوث النزاعية

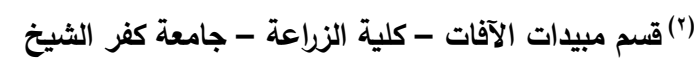

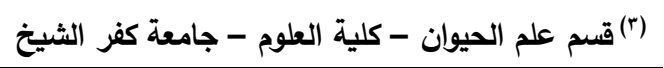

الملخص العربى

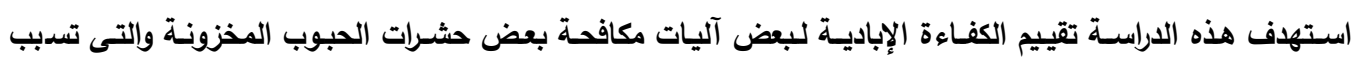

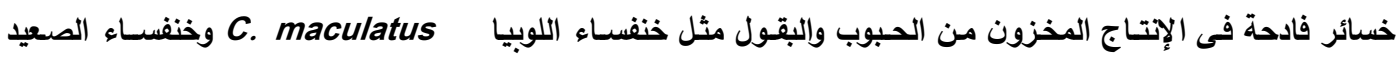
و T. granarium

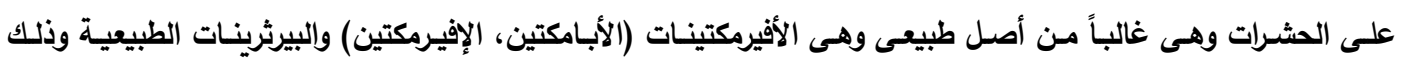

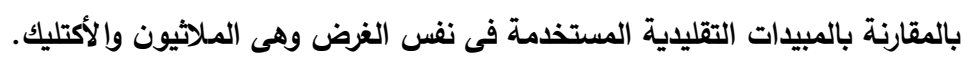

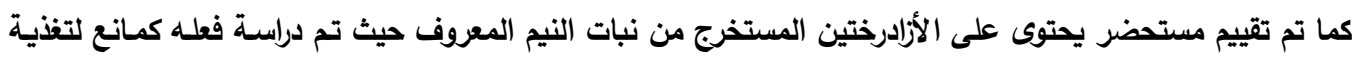

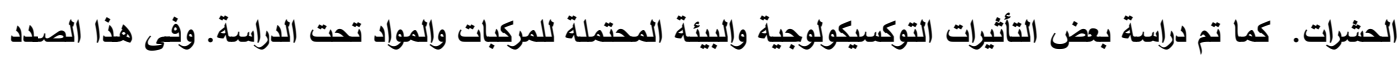

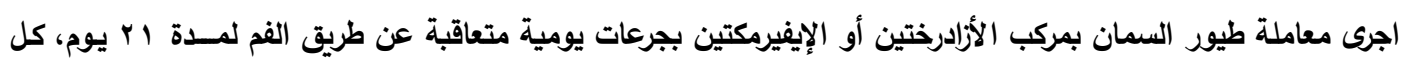

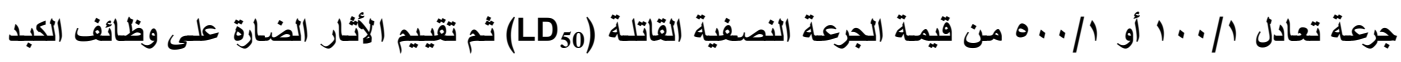
مؤكلاً ذلك بالفحص الهستوباثولوجى.

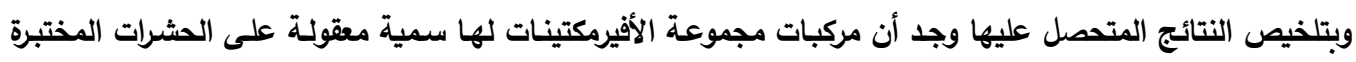

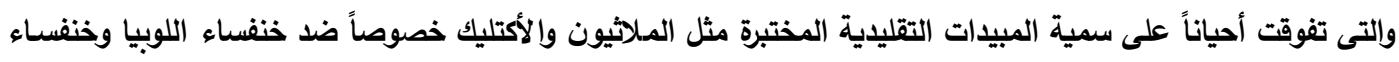

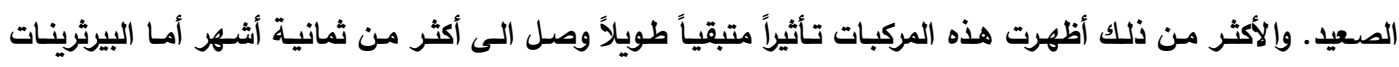

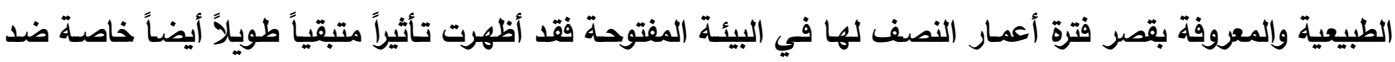

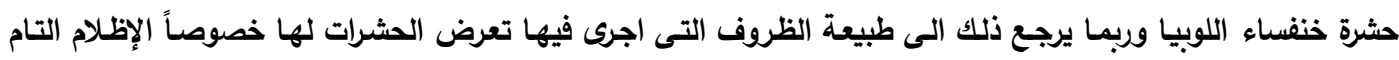

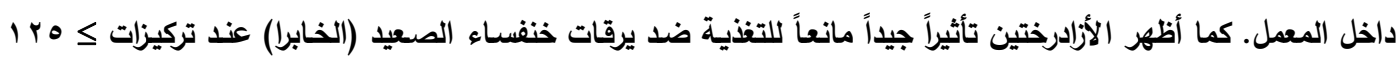

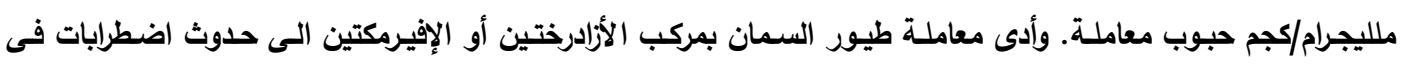

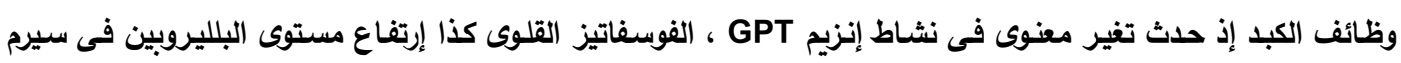

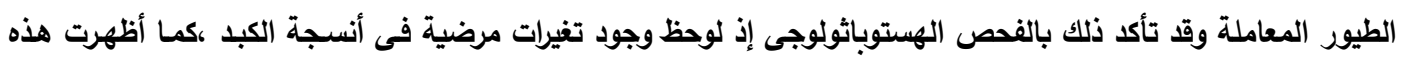

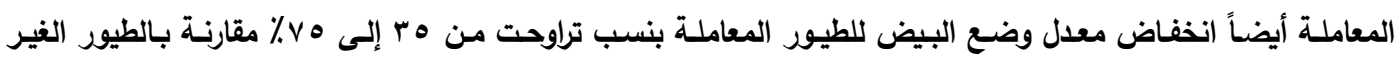
معاملة.

السادة المحكمين

أ.د/ رأفت بـر أبو عـرب محطة بحوث وقاية النبات - محطة بحوث سخا

أ.د/ جمال السيد أبوالغار كلية الزراعة - جامعة المنوفية 